\title{
Similar methodological analysis involving the user experience
}

\author{
Caio Márcio Almeida e Silva ${ }^{\mathrm{a},{ }^{*}}$, Maria Lúcia R. L. Okimoto ${ }^{\mathrm{b}}$ and Raffaela Leane Zenni Tanure ${ }^{\mathrm{c}}$ \\ ${ }^{a}$ Departament of Design, Federal University of Paraná, caiomarcio1001@yahoo.com.br, General Carneiro street, \\ 460, Dom Pedro I Building, $8^{\text {th }}$ floor, Curitiba - PR, Brazil. \\ ${ }^{\mathrm{b}}$ Deparment of Machanical Engineering, Federal University of Paraná, lucia.demec@ufpr.br, Polytechnic Center, \\ Garden of Americas, Curitiba - PR, Brazil. \\ ${ }^{\mathrm{c}}$ Deparment of Production Engineering, Federal University of Rio Grande do Sul, raffaelat@gmail.com, Porto \\ Alegre-RS, Brazil.
}

\begin{abstract}
This article deals with the use of a protocol for analysis of similar methodological analysis related to user experience. For both, were selected articles recounting experiments in the area. They were analyze based on the similar analysis protocol and finally, synthesized and associated.
\end{abstract}

Keywords: Design, similar methodological, user experience

\section{Introduction}

The paper discusses the importance of promoting a similar methodological analysis prior to the development of an experiment involving the experience with the product. About the usability of the product, a search was made, several segments has been identified. Therefore, analyzing the related or similar segments can positively influence research in a segment of experience with the product. The aim of this type of initiative is to investigate how the polls were being developed with the similar theme. Initially, one found the necessary information and influence. Then a similar analysis protocol was developed. Once the protocol was made a collection of articles that addressed the area, or similar areas has been collected. Thus, the articles collected went through a preselection to be analyzed.

\subsection{Usability}

Usability can be understood as a formal technique that can involve users representing the target popula- tion for a particular system. These users are designated to develop critical and typical tasks with a collection of data to be analyzed later. It is therefore essential at any time, if only to know if it worked or not.

The criteria for measuring usability feature established by ISO 9241-11 [3] reflected in:

- Analysis of the characteristics required of the product in a specific usage context;

- Process analysis of interaction between user and product;

- Analysis of efficiency, effectiveness and satisfaction resulting from the use of this product.

There is no general rule that determine or define parameters that allow to combine these measures due to the profile of the variables and components of its dependence to context of use for which usability being described [8]. It is recommended that at least one measure of quality for each item of use [1].

\footnotetext{
${ }^{*}$ Corresponding author.
} 


\subsection{Usability evaluation}

Usability is measured by applying different methods and/or techniques for evaluation of a product or software, at different stages of your development cycle. Each method and/or technique has a specific goal and should be applied according to the stage at which the product or software development is [4].

The methods of usability testing are fundamental, since they require the participation of users using a product or a software implemented to perform tasks. Its application is the primary means to evaluate products and interfaces and reporting certainly real experiences problems during the interaction of users with products or software. Often, project managers no longer perform usability tests citing lack of time, human and financial resources, and also technical difficulty for its realization. This can dramatically affect the final quality of a project from a product or software.

The time required for testing is high because of all the steps necessary for its proper functioning. Depending on the complexity of the product or interface, tests can include multiple sessions, each with one to three hours [11].

The necessary human resources involve real users and evaluators. To guarantee the principle of reliability, tests shall be carried out with more than one user, which is costly and difficult. To enrich the final diagnosis and minimize the problem of subjectivity should allocate more than one tester per test, which entails increasing costs of the project.

And the technical difficulty is due to the total dependence of the quality of the evaluators, since there is no tool that efficiently supports usability testing.

\subsection{Usability evaluation methods}

Some methods are appropriate for certain stages of a project, some have a longer application procedure that other, as well as provide different results. The method must be chosen according to the desired output: the analysis of human errors, performance, usability or design [14].

One should also direct the choice of method by the time available for implementation and review; Despite the terminology can seem a bit vague, in generic terms, consider (remembering that time is relative to the evaluated product): (a) short - less than two hours; (b) medium - from two to six hours and; (c) long - more than six hours [14].This approximation also excludes the time for training and practice of the method that will be applied.

The selection of methods for evaluating the design depends on five factors:

- Accuracy of the methods;

- Criteria to be assessed;

- Acceptability of method;

- Skills of the designers involved in the process;

- Cost-benefit analysis of the methods [14].

In accordance with Stanton \& Young [14] one can apply the varied usability methods in three ways:

- Functional analysis: the spectrum of functions supported by the equipment;

○ Methods: Check-list, Interview, Grids Repertories and Questionnaire.

- Scenario analysis: the performance of particular sequences of activities;

○ Methods: Layouts Analysis, Links Analysis, Heuristic Evaluation, HTA (Hierarchical Task Analyses)

- Structural analysis: non-destructive tests from a user-centric perspective

○ Methods: KLM (Keystroke Level Model), Observation, PHEA (Predictive Human Error Analyses), TAFEI (Task Analysis for Error Identification).

\section{Methodology}

The development of the article occurred in three phases. The first corresponds to the development of the proposed analysis (see section number 3 ). The second refers to a systematic review of articles about experiments applied to the study of usability considering the user experience. For this research one selected the database Science Direct. Access to this platform came through the Journals Portal of CAPES (a public foundation attached to the Ministry of Education with the mission to promote the development of graduate and research programs in Brazil). The survey was restricted to articles published in journals in English and available online.

The steps used to search for articles by Science Direct are illustrated by figure (1). Defined terms for the search engine were: user experience AND usability AND experiment. 

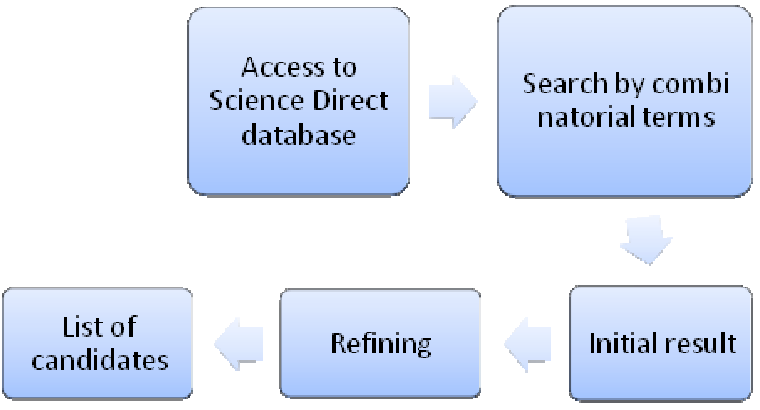

Figure 1: Research process of articles in Science Direct

SOURCE: organized by the authors (2011)

By having the items collected, one proceeded to the third stage of analysis, using the protocol shown in the following section

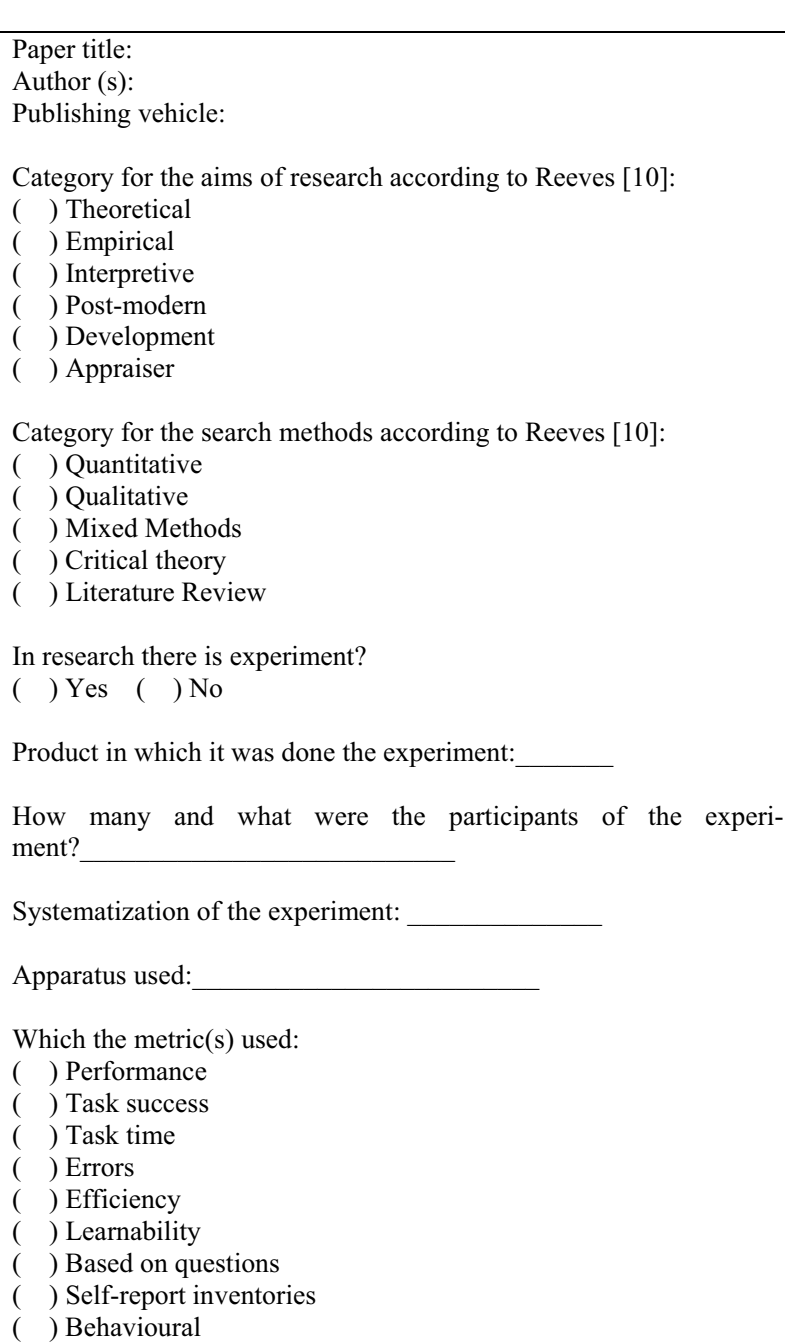

\section{Protocol Analysis}

The Protocol analysis (see table number 1) consists of a database that includes information and specifies aspects related to the methodology for the development of the experiment in design research. The same lists twelve types of information. They are: initial data (article title, author (s), publication vehicle) category for the purposes of research according to Reeves [10], categories for the search methods [10], existence of experiment (duration and participants), metric used, methods or techniques used and / or, statistical processing, apparatus, product used in the experiment, systematization of the experiment, observations about the methodological procedure, and the type of thread used.

Table 1

Proposal that will guide the Similar Methodological Analysis Source: [13]

Which the method (s) and / or technique(s) used:

( ) Layout Analysis

( ) Links Analysis

( ) Task Analysis (Research toolbox)

( ) Heuristic Evaluation

( ) Prototype evaluation (Research toolbox)

( ) Analytical reviews

( ) Card sort (Research toolbox)

( ) Check-list

( ) Collage and modeling with velcro (Research toolbox)

( ) Cultural Probes

( ) Log data

( ) Drawing experience (Research toolbox)

( ) Semantic differential

( ) Photographic diary (Research toolbox)

( ) Interview

( ) Likert scale

( ) Focus group

( ) Generative tools

( ) Grids repertórios

( ) HTA (Hierarchical Task Analyses)

( ) Web Immersion (Research toolbox)

( ) Ergonomics Inspection through checklists

( ) Cognitive inspections

( ) Preventive inspections of errors

( ) Personal Inventory (Research toolbox)

( ) K.L.M. (Keystroke Level Model)

( ) Lists and Drawings (Research toolbox)

( ) Map of behavior (Research toolbox)

( ) Kano model

( ) Guided narration (Research toolbox)

( ) Observation | Via eyetracking

( ) Thinking aloud (Research toolbox)

( ) P.H.E.A. (Predictive Human Error Analyses)

( ) PrEmo (Product Emotion Measurement Instrument)

( ) Questionnaire

( ) S.U.S. (System Usability Scale)

( ) T.A.F.E.I. (Task Analysis for Erros Identification)

( ) Guide Tour (Research toolbox)

( ) Usability Test

Verbalization 


\begin{tabular}{|l|l|}
\hline ( ) Physiological & ( ) Other \\
The duration of the experiment is measured in: & Statistical processing: \\
( ) Milliseconds & Remarks about the methodological procedure: \\
( ) Seconds & $\begin{array}{l}\text { Discussion type used: } \\
\text { ( ) Minutes }\end{array}$ \\
( ) Mours & ( ) Mainly associated to theoretical \\
( ) Days & ( ) Mainly associated to the results \\
( ) Months & Other to objectives and / or to the search question \\
\hline
\end{tabular}

After analysis of similar methodology, one find the possibility to summarize them and present them in a comparative manner. For this purpose, one use a table where the experiments are related: the product used, number and profile of participants, the objectives of the experiment, the metrics used, the methods and \ or techniques used, the statistical treatment, and considerations (see tables number 1, 2 and 3).

Table 2

Comparative synthesis between the methodological similar related to user experience. Part 1.

SOURCE: organized by the authors (2011)

\begin{tabular}{|c|c|c|c|c|c|c|c|c|}
\hline 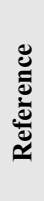 & 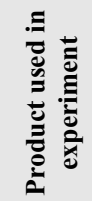 & 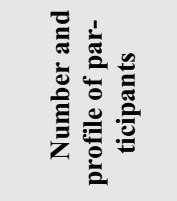 & 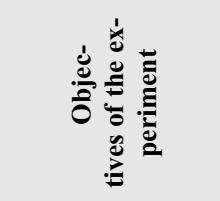 & 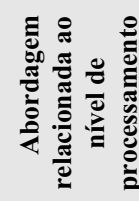 & 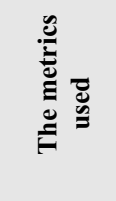 & 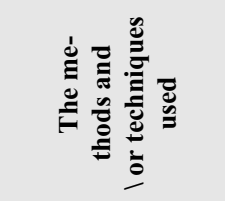 & 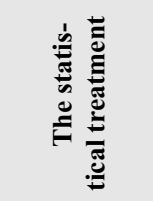 & 突 \\
\hline 15 & $\begin{array}{l}\text { Websit } \\
\mathrm{e}\end{array}$ & $\begin{array}{l}111 \text { under- } \\
\text { graduate } \\
\text { psychology } \\
\text { students ( } 84 \\
\text { females and } \\
27 \text { males), } \\
\text { with a mean } \\
\text { age of } 22 \\
\text { years }\end{array}$ & $\begin{array}{l}\text { aesthetic expe- } \\
\text { rience } \\
\text { perceptions and } \\
\text { evaluations of a } \\
\text { web site }\end{array}$ & visceral & $\begin{array}{l}\text { perfor- } \\
\text { mance } \\
\text { on tasks } \\
\text { auto- } \\
\text { relato }\end{array}$ & $\begin{array}{l}\text { (i) questionnaire } \\
\text { to measure hedon- } \\
\text { ic and aesthetic } \\
\text { value (ii) Subject } \\
\text { Mental Effort } \\
\text { Questionnaire } \\
\text { (SMEQ) }\end{array}$ & $\begin{array}{l}\text { Factor } \\
\text { analysis } \\
\text { Analysis of } \\
\text { variance } \\
\text { (ANOVA) }\end{array}$ & $\begin{array}{l}\text { An effect on objec- } \\
\text { tive performance, } \\
\text { hedonic and Aes- } \\
\text { thetic experience } \\
\text { and mental work- } \\
\text { load its observed } \\
\text { from experimental } \\
\text { manipulation of } \\
\text { presentation prin- } \\
\text { ciples. }\end{array}$ \\
\hline 18 & $\begin{array}{l}\text { Interne } \\
\mathrm{t} \\
\text { Bankin } \\
\mathrm{g} \\
\text { (eBank } \\
\text { ing) }\end{array}$ & $\begin{array}{l}61 \text { partici- } \\
\text { pants (Inter- } \\
\text { net users and } \\
\text { customers of } \\
\text { the involved } \\
\text { Bank) }\end{array}$ & $\begin{array}{l}\text { Explore the dif- } \\
\text { ferences and simi- } \\
\text { larities in expe- } \\
\text { riences with prod- } \\
\text { ucts, generated by } \\
\text { isolated sensory } \\
\text { stimuli. }\end{array}$ & visceral & $\begin{array}{l}\text { perfor- } \\
\text { mance } \\
\text { on tasks } \\
\text { auto- } \\
\text { relato }\end{array}$ & $\begin{array}{l}\text { (i) metaphor } \\
\text { experiment, } \\
\text { (ii) dialogue style } \\
\text { experiment } \\
\text { (iii) likert scale }\end{array}$ & $\begin{array}{l}\text { Analysis of } \\
\text { variance } \\
\text { (ANOVA) }\end{array}$ & $\begin{array}{l}\text { The major impor- } \\
\text { tance of the role of } \\
\text { metaphor is ob- } \\
\text { served in driving the } \\
\text { design of usable P3P } \\
\text { functionality in } \\
\text { eBanking }\end{array}$ \\
\hline 12 & $\begin{array}{l}\text { Websit } \\
\mathrm{e}\end{array}$ & $\begin{array}{l}204 \text { ( } 163 \\
\text { ranging from } \\
18 \text { to } 45 \text { years } \\
\text { of age and } \\
41 \text { people } \\
\text { over } 46 \text { years) }\end{array}$ & $\begin{array}{l}\text { evaluate the usa- } \\
\text { bility of a number } \\
\text { of visual naviga- } \\
\text { tion tools and the } \\
\text { effect } \\
\text { for two age } \\
\text { groups ( } 18-45 \text { and } \\
>46)\end{array}$ & $\begin{array}{l}\text { Beha- } \\
\text { vioral }\end{array}$ & $\begin{array}{l}\text { perfor- } \\
\text { mance } \\
\text { on tasks } \\
\text { (Success } \\
\text { and tasks } \\
\text { times) } \\
\text { auto- } \\
\text { relato }\end{array}$ & $\begin{array}{l}\text { 'think-aloud' } \\
\text { technique } \\
\text { usability ques- } \\
\text { tionnaire }\end{array}$ & $\begin{array}{l}\text { Analysis of } \\
\text { variance } \\
\text { (ANOVA) } \\
\text { Tukey's } \\
\text { HSD, the } \\
\text { Bonferroni } \\
\text { and Games- } \\
\text { Howell } \\
\text { post hoc } \\
\text { procedures }\end{array}$ & $\begin{array}{l}\text { Age has a signifi- } \\
\text { cant effect on 3D } \\
\text { navigation } \\
\text { using desktop sys- } \\
\text { tems. Age must be } \\
\text { considered as an } \\
\text { element in the de- } \\
\text { sign process }\end{array}$ \\
\hline
\end{tabular}


Table 3

Comparative synthesis between the methodological similar related to user experience. Part 2. Source: organized by the authors (2011)

\begin{tabular}{|c|c|c|c|c|c|c|c|c|}
\hline 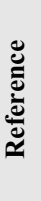 & 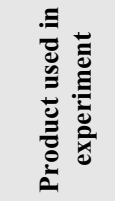 & 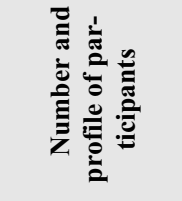 & 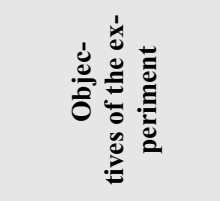 & 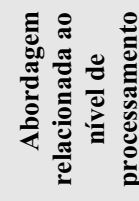 & 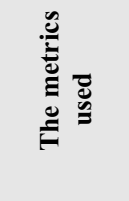 & 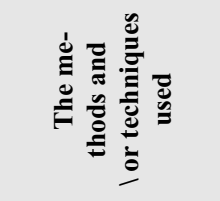 & 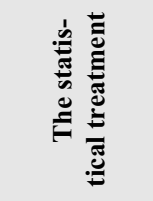 & 突 \\
\hline 6 & Website & $\begin{array}{l}40 \text { partici- } \\
\text { pants, ranging } \\
\text { from } 20 \text { to } 60 \\
\text { years of age }\end{array}$ & $\begin{array}{l}\text { explore the notion } \\
\text { of "user satisfac- } \\
\text { tion" }\end{array}$ & Visceral & $\begin{array}{l}\text { partici- } \\
\text { pants just } \\
\text { browse } \\
\text { the } \\
\text { sites to } \\
\text { form an } \\
\text { opinion } \\
\text { about } \\
\text { them. } \\
\text { Inspec- } \\
\text { tion of } \\
\text { each site } \\
\text { was } \\
\text { followed } \\
\text { by an } \\
\text { unstruc- } \\
\text { tured } \\
\text { interview } \\
\text { and com- } \\
\text { pletion of } \\
\text { the } \\
\text { WAMMI }\end{array}$ & $\begin{array}{l}\text { unstructured in- } \\
\text { terviews and Web } \\
\text { site Analysis } \\
\text { MeasureMent } \\
\text { Inventory } \\
\text { (WAMMI) rating } \\
\text { scales }\end{array}$ & $\begin{array}{l}\text { Analysis of } \\
\text { variance } \\
\text { (ANOVA) } \\
\text { Post Hoc } \\
\text { Bonferroni } \\
\text { test }\end{array}$ & $\begin{array}{l}\text { WAMMI may not } \\
\text { capture the element } \\
\text { called 'emotion' }\end{array}$ \\
\hline 5 & $\begin{array}{l}\text { Comput- } \\
\text { er and } \\
\text { accesso- } \\
\text { ries }\end{array}$ & $\begin{array}{l}24 \text { partici- } \\
\text { pants. Their } \\
\text { ages ranged } \\
\text { from } 19 \text { to } 37 \\
\text { years }\end{array}$ & $\begin{array}{l}\text { investigate the } \\
\text { effects of non- } \\
\text { obtrusive feed- } \\
\text { back on conti- } \\
\text { nuous lifted } \\
\text { hand/finger beha- } \\
\text { viour, } \\
\text { task performance } \\
\text { and comfort }\end{array}$ & $\begin{array}{l}\text { Beha- } \\
\text { vioral }\end{array}$ & $\begin{array}{l}\text { perfor- } \\
\text { mance } \\
\text { on tasks } \\
\text { (Effec- } \\
\text { tiveness } \\
\text { and Effi- } \\
\text { ciency), } \\
\text { Satisfac- } \\
\text { tion } \\
\text { question- } \\
\text { naires } \\
\text { responses } \\
\text { and Task } \\
\text { difficulty } \\
\text { analysis }\end{array}$ & $\begin{array}{l}\text { Performance a } \\
\text { standardized } \\
\text { computer task } \\
\text { with two levels of } \\
\text { task difficulty }\end{array}$ & $\begin{array}{l}\text { Analysis of } \\
\text { variance } \\
\text { (ANOVA) } \\
\text { Tukey HSD } \\
\text { was used } \\
\text { for post hoc } \\
\text { testing }\end{array}$ & $\begin{array}{l}\text { the importance of } \\
\text { including user expe- } \\
\text { riences when } \\
\text { investigating usa- } \\
\text { bility of feedback } \\
\text { signals }\end{array}$ \\
\hline 9 & Website & $\begin{array}{l}418 \text { web users } \\
\text { (ranging of } \\
\text { age is early } \\
\text { twenties) in } \\
\text { the first } \\
\text { study, } 52 \text { web } \\
\text { designers for } \\
\text { the experi- } \\
\text { ment and } 515 \\
\text { undergra- } \\
\text { duates in the } \\
\text { survey }\end{array}$ & $\begin{array}{l}\text { identify critical } \\
\text { factors that are } \\
\text { closely related to } \\
\text { the aesthetic } \\
\text { fidelity of web } \\
\text { pages }\end{array}$ & Visceral & $\begin{array}{l}\text { Behaviou } \\
\text { ral } \\
\text { self- } \\
\text { reported }\end{array}$ & $\begin{array}{l}\text { semantic differen- } \\
\text { tial } \\
\text { verbal and action } \\
\text { protocols } \\
\text { Likert scale } \\
\text { questionnaire }\end{array}$ & $\begin{array}{l}\text { confirmato- } \\
\text { ry factor } \\
\text { analysis } \\
\text { Average } \\
\text { Variance } \\
\text { Extracted } \\
\text { (AVE) } \\
\text { Analysis of } \\
\text { variance } \\
\text { (ANOVA) }\end{array}$ & $\begin{array}{l}\text { In order to identify } \\
\text { the critical factors a } \\
\text { exploratory study } \\
\text { with web users, a } \\
\text { longitudinal experi- } \\
\text { ment with profes- } \\
\text { sional web design- } \\
\text { ers, and } \\
\text { finally an online } \\
\text { survey with web } \\
\text { users were con- } \\
\text { ducted. }\end{array}$ \\
\hline
\end{tabular}


Table 4:

Comparative synthesis between the methodological similar related to user experience. Part 3.

SOURCE: organized by the authors (2011

\begin{tabular}{|c|c|c|c|c|c|c|c|c|}
\hline 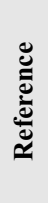 & 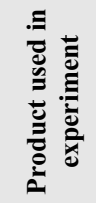 & 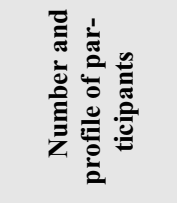 & 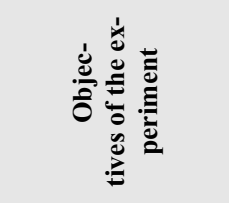 & 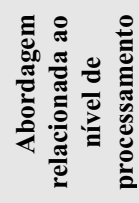 & 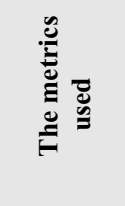 & 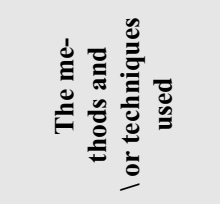 & 总 & 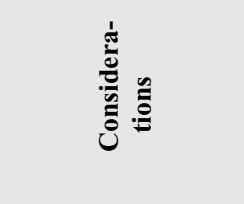 \\
\hline 2 & $\begin{array}{l}\text { Wiki } \\
\text { Sistem }\end{array}$ & $\begin{array}{l}77 \text { undergra- } \\
\text { duate students } \\
\text { in psychology } \\
\text { of the first } \\
\text { year. } 18 \text { were } \\
\text { males and } 59 \\
\text { were female. } \\
\text { The average } \\
\text { age of } 18.78 \\
\text { years. All } \\
\text { participants } \\
\text { had used a } \\
\text { computer for } \\
\text { at least a year. }\end{array}$ & $\begin{array}{l}\text { assess the expe- } \\
\text { rience of novice } \\
\text { users when they } \\
\text { interact with the } \\
\text { computer }\end{array}$ & Visceral & $\begin{array}{l}\text { perfor- } \\
\text { mance } \\
\text { on tasks } \\
\text { (Success) }\end{array}$ & $\begin{array}{l}\text { questionnaire } \\
\text { binary yes/no } \\
\text { Internal } \\
\text { consistency } \\
\text { (Cronbach alpha) }\end{array}$ & $\begin{array}{l}\text { Analysis of } \\
\text { variance } \\
\text { (ANOVA) }\end{array}$ & $\begin{array}{l}\text { Using a built-in } \\
\text { tutorial reduces } \\
\text { anxiety and the } \\
\text { technological bar- } \\
\text { riers to wiki editing. }\end{array}$ \\
\hline 19 & $\begin{array}{l}\text { Websit } \\
\text { es }\end{array}$ & 125 & $\begin{array}{l}\text { explore the con- } \\
\text { gruence of percep- } \\
\text { tions aesthetic } \\
\text { value over time by } \\
\text { manipulating the } \\
\text { design aesthetic of } \\
\text { web pages and } \\
\text { studying the rela- } \\
\text { tionship between } \\
\text { usability and } \\
\text { aesthetic value }\end{array}$ & Visceral & $\begin{array}{l}\text { self- } \\
\text { reported }\end{array}$ & $\begin{array}{l}\text { Thinking aloud } \\
\text { Post-task } \\
\text { evaluation }\end{array}$ & $\begin{array}{l}\text { Analysis of } \\
\text { variance } \\
\text { (ANOVA) }\end{array}$ & $\begin{array}{l}\text { Were planned more } \\
\text { than an experiment. }\end{array}$ \\
\hline 16 & $\begin{array}{l}\text { Interne } \\
\mathrm{t} \\
\text { Bankin } \\
\mathrm{g} \\
\text { (eBank } \\
\text { ing) }\end{array}$ & $\begin{array}{l}141 \text { partici- } \\
\text { pants, users } \\
\text { of internet } \\
\text { banking, } \\
\text { divided into } \\
\text { two groups: } \\
\text { one with } \\
\text { participants } \\
\text { under the age } \\
\text { of } 35 \text { years } \\
\text { and another } \\
\text { with the rest. }\end{array}$ & $\begin{array}{l}\text { investigate the } \\
\text { effect of expe- } \\
\text { rience of service } \\
\text { users, from the } \\
\text { perception of } \\
\text { usability and } \\
\text { security, to inform } \\
\text { the design of } \\
\text { security technolo- } \\
\text { gy usable for two- } \\
\text { factor authentica- } \\
\text { tion in eBanking } \\
\text { in order to max- } \\
\text { imize customer } \\
\text { acceptance and } \\
\text { adoption. }\end{array}$ & $\begin{array}{l}\text { Beha- } \\
\text { vioral }\end{array}$ & $\begin{array}{l}\text { perfor- } \\
\text { mance } \\
\text { on tasks } \\
\text { (Success) } \\
\text { self- } \\
\text { reported }\end{array}$ & $\begin{array}{l}\text { observation } \\
\text { questionnaire } \\
\text { Likert scale }\end{array}$ & $\begin{array}{l}\text { Analysis of } \\
\text { variance } \\
\text { (ANOVA) }\end{array}$ & $\begin{array}{l}\text { The time was not } \\
\text { measured. The au- } \\
\text { thors preferred } \\
\text { clinging to the } \\
\text { comments and in- } \\
\text { puts of the question- } \\
\text { naires }\end{array}$ \\
\hline 17 & $\begin{array}{l}\text { Web- } \\
\text { site } \\
\text { (Wiki- } \\
\text { pedia) }\end{array}$ & $\begin{array}{l}128 \text { Under- } \\
\text { graduate } \\
\text { Psychology } \\
\text { students (100 } \\
\text { females and } \\
28 \text { males), } \\
\text { with average } \\
\text { age of } 22.79 \\
\text { years. }\end{array}$ & $\begin{array}{l}\text { discover that the } \\
\text { perceptions of } \\
\text { product attributes } \\
\text { and variables of } \\
\text { technology accep- } \\
\text { tance. }\end{array}$ & $\begin{array}{l}\begin{array}{l}\text { Beha- } \\
\text { vioral }\end{array} \\
\text { Visceral }\end{array}$ & $\begin{array}{l}\text { perfor- } \\
\text { mance } \\
\text { on tasks } \\
\text { (Success) }\end{array}$ & $\begin{array}{l}\text { semantic differen- } \\
\text { tial } \\
\text { inventory } \\
\text { questionnaire } \\
\text { Likert scales }\end{array}$ & $\begin{array}{l}\text { Analysis of } \\
\text { variance } \\
\text { (ANOVA) }\end{array}$ & $\begin{array}{l}\text { Discussion guided } \\
\text { by the following } \\
\text { themes: the role of } \\
\text { aesthetics in differ- } \\
\text { ent stages of product } \\
\text { use, the role of } \\
\text { perceived Pleasure } \\
\text { in technology accep- } \\
\text { tance, an integrated } \\
\text { conceptual frame- } \\
\text { work and the prod- } \\
\text { uct as a fallacy-of } \\
\text { fixed effect. }\end{array}$ \\
\hline
\end{tabular}


After the presentation of the synthesis of data from similar methodology involving the user experience, it is possible to identify some relations between them. Next, we'll discuss each topic listed in the table: participating, analysis objects, goals, metrics, methods and techniques and statistical processing.

In this context, one identified as more analysis object used in searches the website. It was a total of eight studies. In addition, virtual systems were evaluated and programmes of the type "internet banking".

Regarding the number of participants in each experiment, we identified a number of 1,329 for the ten experiments. This total resulted in an average of approximately 133 participants per experiment. Other data to be considered, is that four experiments showed the total number of participants between 1 and 100 individuals. Four made the total number of participants between 101 and 200 individuals; one, the number of participants between 201 and 300 individuals. Finally, one experiment showed a number of participants between 401 and 500 individuals.

Concerning the goals, one categorize the articles into two groups: those that focused exploration, and that had as objective the evaluation. Thus, were identified seven experiments with the purpose of exploitation. The remaining three were categorized in the group of experiments with the purpose of evaluation.

When it comes to metrics, have been identified only three metrics in the ten experiments. They are: performance (successful task), performance (time of task), performance (efficiency), self-reported and behavioral. In some experiments, were used more than one metric. Thus, the most commonly used metric in this group of similar methodological were performance (success of the task), totaling seven times. Among them, seven were related to the success of the task, a time-related and other task related to efficiency. Other six experiments used metrics of self-report and, finally, the remaining two used the behavioral metrics.

After the metrics have been identified methods and techniques used in the experiments. In all, about ten different methods and techniques mentioned, there may be more than one in an experiment. They are: the questionnaire, with six uses; likert scale, with four uses, think-aloud, with two uses; interview with one use; semantic differential scale with two uses; observation, post-task analysis, protocol, binary scale, and customer inventory with one use.

The link between the approaches and levels of processing of Norman [7], has shown that six of them visceral. Three of the approaches has proved beha- vioral. And, finally, a mixed approach proved both as mixed as behavioral.

Finally, statistical treatments were appointed. All experiments have used at least the analysis of variance (ANOVA). Combined with this, sometimes other statistical tests were used, such as: factor analysis, two uses; the Average Variance Extracted, one use; Post Hoc Bonferroni, one use; and Tukey's HSD, two uses.

\section{Final considerations}

The article dealt with the use of a protocol for similar analysis methodology related to user experience. For this purpose, were selected articles recounting experiments in the area. They were analysed based on the similar analysis protocol and finally, synthesized and listed in a table.

In developing the same, we must consider the importance of developing or using a tool to guide a review and analyze the methodology of a similar area in a research project. A relevant data identified in the experi-ments analyzed unanimous was the use of analysis of variance in the processing of data.

As recommendation for future research in the area it is suggested that this same procedure is done with research in the area of experience with the product. Thus, one can have a panorama from a related area, as well as the possibility to relate the two types of searches.

\section{References}

[1] Bevan, N.; Macleod, M. Usability measurement in context. Behaviour and Information Technology. n. 13, 1994, p. 132145.

[2] COWAN, B. R.; Jack, M. A. Exploring the wiki user experience: The effects of training spaces on novice user usability and anxiety towards wiki editing. Interacting with Computers, Volume 23, Issue 2, March 2011, Pages 117-128

[3] International Standartization Organization. ISO 9241-11: Ergonomic requirements for office work with visual display terminals, Part 11: guidance on usability.1998.

[4] Jeffries, R. and DESURVIRE, H. Usability testing vs Heuristic evaluation: was there a contest, In: ACM SIGCHI bulletin, 1992, v. $24, \mathrm{n}^{\circ} 4$

[5] Korte E., M. de ; Huysmans , M.A., Jong, A. M. de; VAN DE VEN, J. G. M.; RUIJSENDAAL, M. Effects of four types of non-obtrusive feedback on computer behaviour, task performance and comfort. Applied Ergonomics, In Press, Corrected Proof, Available online 2 July 2011 
[6] Lindgard, G.; Dudek, C.. What is this evasive beast we call user satisfaction? Interacting with Computers, Volume 15, Issue 3, June 2003, Pages 429-452

[7] Norman, Donald A. Emotional Design - Why We Love (or Hate) Everyday Things. New York: Basic Books, 2004.

[8] Okimoto, M. L. L. R.; Guedes, W. M.. Procedimentos para a avaliação quantitativa de usabilidade em painéis de instrumentos. Revista D.: Design, Educação, Sociedade e Sustentabilidade. Porto Alegre: UniRitter; n.1, 2006. p. 81-99

[9] Park, S.; Choi, D.; Kim, J. Critical factors for the aesthetic fidelity of web pages: empirical studies with professional web designers and users.Interacting with Computers, Volume 16, Issue 2, April 2004, Pages 351-376

[10] Reeves, Thomas C. Rigorous and socially responsible interactive learning research. In: Journal of Interactive Learning Research, $1998 . \quad$ Disponível em: $<$ http://www.aace.org/pubs/jilr/intro.html $>$

[11]Rocha, H. V. \& Baranauskas, M. C.C.. Design e Avaliação de Interfaces humano-computador. Escola de Computação Unicamp: São Paulo, 2000.

[12] Sayer, H. Desktop virtual environments: a study of navigation and age. Interacting with Computers, Volume 16, Issue 5, October 2004, Pages 939-956

[13] Silva C. M. AL; Okimotto, M. L. Intuitividade no uso de produtos: procedimento de avaliação da experiência com o produto no design. Projeto de Pesquisa (mestrado em design), Progama de pós-Graduação em Design, Universidade Federal do Paraná, Curitiba, 2011

[14] Stanton, N. A.; Young, M. S. A guide to methodology in ergonomics: designing for human use. London: Taylor \& Francis, 1999.

[15] Van Schaik, P; Ling, J. Modelling user experience with web sites: Usability, hedonic value, beauty and goodness . Interacting with Computers, Volume 20, Issue 3, May 2008, Pages 419-432

[16] Van Schaik, P.; Ling, Jonathan. An integrated model of interaction experience for information retrieval in a Web-based encyclopaedia. Interacting with Computers, Volume 23, Issue 1, January 2011, Pages 18-32

[17]Van Schaik, P.; Ling, Jonathan. The role of context in perceptions of the aesthetics of web pages over time. International Journal of Human-Computer Studies, Volume 67, Issue 1, January 2009, Pages 79-89

[18] Weir, C. S.; Anderson, J. N.; Jack, M. A.. On the role of metaphor and language in design of third party payments in eBanking: Usability and quality. International Journal of HumanComputer Studies, Volume 64, Issue 8, August 2006, Pages 770-784

[19] Weir, C. S.; Douglas, G.; Richardson, T. Jack, Mervyn. Usable security: User preferences for authentication methods in eBanking and the effects of experience. Interacting with Computers, Volume 22, Issue 3, May 2010, Pages 153-164 